\title{
The Polish elections to the European Parliament in 2014 as shown in the Polish press
}

Poland has already had three European elections since its accession to the European Union. On May 25, 2014, the Polish public elected fifty-one members of the European Parliament (MEPs) for another term of five years. Similarly to the 2004 and 2009 elections, the main concern of Polish journalists was voter turnout. This time, the turnout amounted to $23.84 \%$ giving the leading position to the Civic Platform (PO) party, which won $32.13 \%$ of votes. Law and Justice (PiS) came second with $31.78 \%$ votes, followed by the Democratic Left Alliance (SLD - 9.44\%), the New Right (NP - 7.15\%) and the Polish People's Party (PSL - 6.8\%). United Poland, the coalition Europa Plus-Your Move (EPTR), Poland Together, the National Movement, the Green Party of Poland and the Direct Democracy Election Committee failed to achieve the election threshold of 5\%.

The most influential Polish newspapers and magazines were assessing the strategy of different parties' election committees throughout the entire campaign. New faces of the campaign, alongside the profiles of those MEPs who were battling to get to Strasbourg once again, were presented. The style of the campaign, the language of TV election spots and the means the parties used in order to generate social support were stressed. Once again, Polish journalists highlighted the paradox of domestic issues being discussed in order to win a seat in the EP and of treating these elections as a warm-up to the national elections. ${ }^{1}$

\section{Before the elections}

The EP election campaign started in early April 2014. Initially, the Polish press did not feature many profiles of candidates for seats in Strasbourg. As the elections drew nearer, however, the most popular newspapers and magazines began to publish commentaries on the election strategies of the different party committees and presented candidate profiles.

At that time, the "Wprost" weekly published an interesting article presenting new faces of the campaign proposed by different parties as candidates for MEPs.

In her article Pudelek Europejski [European Poodle ${ }^{2}$, Katarzyna Nowicka presented the popular celebrities, known from the media, who were supposed to become

1 Cf.: A. Barabasz, Prasa polska o wyborach do Parlamentu Europejskiego w 2009 roku, "Rocznik Integracji Europejskiej” 2009, no 3.

${ }^{2}$ This is an allusion to the first Polish website dedicated to celebrities "Pudelek" (poodle) (translator's note). 
the driving force behind different political parties and attract voters reluctant to take part in the European elections. Although the journalist believed these candidates were not really likely to win European mandates, they performed important tasks for their parties: "they were to play the role of a 'hare' driving people to the polls" (Nowicka, 2014). Wojciech Jabłoński, an expert on political marketing, also assessed these tactics and he did not believe that the celebrities would be successful in the European elections: "they are placed so low on the ballots that they do not stand a chance of winning a seat in Brussels" (ibid.). Sociologist and political commentator, Jarosław Flis, spoke in a similar vein: "most celebrities do not stand a chance of scoring a good result; either they do not realize it, or they are not aware of the mechanisms ruling politics, or they are driven by vanity" (ibid.). The author of this article considered the following to be the most important faces in this campaign: the President of Warta Poznan football club Izabela Łukomska-Pyżalska, volleyball player Michał Bąkiewicz, actress Weronika Marczuk, swimmer Otylia Jędrzejczak, football player Maciej Żurawski, handball trainer Bogdan Wenta and boxer Tomasz Adamek.

On April 22, 2014, the newspaper "Rzeczpospolita", which tends to sympathize with the Polish right wing, presented the leading Polish MEPs who distinguished themselves in the 2009-2914 parliamentary term. "Rzeczpospolita" journalists put the following MEPs on the podium: Konrad Szymański (PiS), Danuta Hübner (PO), Jacek Saryusz-Wolski (PO), Jan Olbrycht (PO), Jerzy Buzek (PO), Sidonia Jędrzejewska (PO), Paweł Kowal (United Poland), Bogusław Sonik (PO), Rafał Trzaskowski (PO), Lena Kolarska-Bobińska (PO) and Róża Thun (PO). According to "Rzeczpospolita" journalist Anna Słojewska, although these MEPs have different ideological origins and represent different political parties, they have similar properties allowing them to work successfully in the EP: diligence, conciliatoriness, as well as the ability to build coalitions across political and national divisions (Słojewska, 2014). The author also stressed that in the upcoming campaign the candidates would be focusing on issues of the utmost importance for the future of the European Union and of Poland, that is energy security, climate policy, regional policy, the sensible spending of tens of billions of euro allocated to Poland, Eastern policy and the policy response to the aggressive behavior of Russia (ibid.).

Writing for "Przegląd", Jerzy Domański addressed the issue of candidate qualifications and observed that, in these difficult and unpredictable times, we should send a team possessing post-national skills to Strasbourg. He suggested that those who "confused Brussels with local or national elections" be given a red card (Domański, 2014a).

On April 24, Marcin Pieńkowski analyzed the election strategy of PiS in "Rzeczpospolita", and put Jarosław Kaczyński's cards on the table in a game of election poker. In the article Triki PiS z kandydatami [PiS's tricks with candidates], he noted that the PiS election lists began with less well-known politicians, which followed from the lesson learned in the former European elections in 2009, when, due to mistakes by the party, fifteen MEPs were elected, only seven of whom were still members of PiS (Pieńkowski, 2014). Therefore, in these elections, Jarosław Kaczyński decided to count on loyal and trusted politicians, such as Anna Fotyga, Karol Karski and Ryszard Czarnecki. The remaining PiS candidates, although listed on the remote places on the 
ballots, and not seeming to stand a chance of coming first, were frequently running the campaign on their own and with their own money, afraid of the headquarters' disapproval if they did not. In the opinion of political marketing expert, Błażej Pobożny of Warsaw University, this move allowed Jarosław Kaczyński to "minimize the risk of people quitting the party after the elections, while at the same time boasting that he was sending academics to the European Parliament" (ibid.).

One month before the elections, "Rzeczpospolita" warned that the turnout in the approaching elections could be low. In the journalists' opinions, this was due to voter ignorance and the arrogance of the politicians. In his article Wyborcy nie widza kampanii [Voters don't see the campaign], Paweł Majewski observed that modern techniques to influence voters were failing. Election spots posted on the internet in practice did not reach voters and could not provide information about the views of different parties and candidates. He referred to an assessment made by expert on political analysis, Maria Nowina-Konopka, who said that "people forward election spots to one another as a joke, rather than as part of an election campaign" (Majewski, 2014 a). She also observed that politicians were not able to take advantage of the internet as "the spots look like commercials in the traditional media. They are not interactive" (ibid.). The "Rzeczpospolita" journalist listed the following spots as those most frequently watched for entertainment: Anna Kubica from ETPR impersonating journalist Anna Jaworowicz, Ryszard Kalisz from the same party, who pretended to be counting the votes cast for himself, deducting $100 \mathrm{~cm}$ from his waist measurement, and another representative of EPTR, Anna Słomkowska, who outright refused to discuss the Crimean issue. In Majewski's opinion, the range of online campaigns was highly limited and voters were still accustomed to the traditional TV coverage of the election campaign and candidates' views.

Polish journalists frequently referred to the very high salaries of MEPs that greatly exceed those of members of the Polish Parliament, suggesting that this was one of the main motivations for MEP candidates. Some journalists went as far as to suggest that Polish MEPs had developed a special, unofficial system of making a profit, called 'pressing Brussels sprouts', and encompassing a range of tricks used when calculating daily allowances, travel expenses and hotels (Stankiewicz, 2014). Andrzej Stankiewicz from "Rzeczpospolita" presented a list of MEPs from the preceding term who got considerably richer owing to their parliamentary status. He also remarked that the closer the elections drew, the more they were trying to 'impoverish' themselves in their asset declarations.

The campaign was in full swing in early May. Different political groups were battling for votes in different ways. They frequently applied negative campaign mechanisms.

"Gazeta Wyborcza" discussed the crude election campaign of the anti-European National Movement. Agata Kondzińska from "Gazeta Wyborcza" criticized the conduct of the party's activists, who on May 1 gathered in front of the offices of the European Commission in Warsaw to trample on the Union flag and spit on it. The author observed that its political platform, promoted by the members of the All-Polish Youth and the National Radical Camp, stressed the following:

- to build a Europe of homelands rather than a Europe of nations; 
- to fight European leftism, so as to protect the family, and by extension the traditional roles of men and women;

- to take care of Poles abroad, for instance to ensure respect for the rights of the Polish minority in Lithuania;

- to stop further reductions of $\mathrm{CO}_{2}$ emissions by the $\mathrm{EU}$, as it is expensive for the Polish economy;

- to introduce the Polish historical narrative to the international arena to stop talk about Polish death camps (Kondzińska, 2014).

In the author's opinion, the National Movement did not stand a real chance to exceed the election threshold, since, according to all the polls, its support was within the brackets of $1-2 \%$. Nevertheless, the Movement did not give up its fight for Strasbourg and was taking serious steps to attract public attention. It was seeking voters among football fans and in radical circles, which in Kondzińska's opinion could bear on the final results of other right-wing parties in Poland.

Less than three weeks prior to the elections, "Gazeta Wyborcza" published an interview with Paweł Ciacek from Millward Brown Polska, a company dealing with social surveys and studies in communications, on the EP election campaign of different political parties. This sociologist noted that, as was the case in the past, the European elections did not arouse much social interest and it was quite difficult to indicate who would be the winner: "although we can see the candidates, and the role of the 'engines' - the number ones on the lists - is significant, this does not look like a battle for ultimate victory. It is generally not easy to determine who won these elections. The electoral law does not make it any easier, and translating a vote cast into the mechanism of indicating a given representative is particularly blurred" (Kublik, 2014). In the same interview, Ciacek indicated the best slogan in this election, which in his opinion was "Choose a deputy who thinks the way YOU do!" This slogan was intended to stimulate higher voter turnout and attract to the polls the disenchanted electorate who had reluctantly been taking part in European elections since 2004.

In the same period, "Rzeczpospolita" did not forecast success for EPTR. In the article $W$ poszukiwaniu kozła ofiarnego [Looking for a scapegoat], a journalist of "Rzeczpospolita", Eliza Olczyk stressed the disputes and criticism between both Aleksander Kwaśniewski and Janusz Palikot. The former Polish ex-President accused the latter, the leader of EPTR, of being anti-clerical, which was actually harmful to the party's interests at a time when John Paul II was finally being canonized, which coincided with the European elections campaign and in which polls indicated that this event was particularly important for $98 \%$ of Poles. Janusz Palikot in turn, reproached Aleksander Kwaśniewski for going to Rome to take part in the canonization alongside opponents from the ruling party. In the journalist's opinion, this was a lead in to a settling of accounts after the elections, as a majority of polls on the election preferences of Poles did not forecast EPTR as able to exceed the 5\% election threshold (Olczyk, 2014).

The bristly friendship between Kwaśniewski and Palikot was also commented upon in other magazines. Anna Pawlicka from "Newsweek" said that the visit to Rome was inspired by President Bronisław Komorowski and ex-President Lech Wałęsa, and it would have been simply inappropriate for Kwaśniewski not to accept the invitation. 
The journalist was of the opinion that the leader of EPTR expected Kwaśniewski to make sacrifices and be heroic in the fight against the Church, and that he must have miscalculated (Pawlicka, 2014a). Agnieszka Burzyńska and Anna Gilewska observed in "Wprost" that the nearer the elections drew, the more Aleksander Kwaśniewski "was becoming a burden for Palikot on account of his gas business ventures in Ukraine" (Burzyńska, 2014).

Two weeks before the elections to the EP, the journalists from "Rzeczpospolita" argued that, similar to the previous European campaigns (in 2004 and 2009), the leitmotif of the election activities of politicians were Polish problems rather than European issues. Therefore, in the second half of the campaign, the two leading political parties in Poland, $\mathrm{PO}$ and PiS, set off to meet their electorates and ensure their votes by various means. According to Paweł Majewski from "Rzeczpospolita", PiS visited its traditional strongholds: the regions of Mazowsze, Podkarpacie and Lubelszczyzna in order to mobilize their cast iron electorate. Given the Ukrainian crisis, the PO party in turn stressed the issues of state security, therefore "Donald Tusk had breakfast with a war veteran and celebrated with firefighters [...] PO is also going to take advantage of such events as the Days with the Polish Army, organized in Mińsk Mazowiecki" (Majewski, 2014b).

Professor Kazimierz Kik from Jan Kochanowski University in Kielce stressed the different motivations of the leaders of the main political parties in Poland that were emerging during the EP election campaign, although they were frequently not related to those elections. In his opinion, an election victory for PO and Prime Minister Donald Tusk would mean them obtaining significant posts in EU institutions, primarily thanks to the party's membership of the largest group in the EP - the European People's Party. Therefore, PO's election lists opened with the names of present and former members of Polish parliament, MEPs and ministers. According to Kik, the leader of the main opposition party, PiS, was making an utterly different assumption. The most important objective for him is to "take away the political initiative from PO on the national arena" (Kik, 2014). He was going to attain this objective filling the PiS lists mainly with trusted and loyal politicians without greater ambitions, because he was treating the European elections as a useful test before the ultimate goal of winning the parliamentary elections in Poland (ibid.). The Deputy Chairman of the Political Science Committee of the National Academy of Sciences stressed that for the leaders of the other political parties standing for the EP, namely PSL, SLD and EPTR, the result of the election struggle for mandates to the EP meant "to be or not to be" on the political arena. Other election committees, such as the Congress of the New Right, wanted to use the elections on May 25, first and foremost, to raise their profile before the parliamentary elections in Poland the following year. In his extensive article, Kazimierz Kik analyzed the achievements of our MEPs in the 2009-2014 term, also outlining the profile of a desirable European 'co-legislator' as a highly competent and diligent person. In his opinion, such an individual should be characterized by high academic qualifications in an area related to legislation and establishing EU institutions (sociology, economics, law and political science). He also suggested that few Polish MEPs were ready to meet these criteria, and the EP was merely a 'waiting room' for them before better times arrived, as well as a source of considerable income. 
Tomasz Sommer, writing for "Najwyższy Czas" - a publication of Janusz Korwin-Mikke's ${ }^{3}$ party - forecasted that the New Right would exceed the election threshold, thereby winning the 2014 European elections, in his opinion. He also observed that Janusz Korwin-Mikke would soon become a star of the new EP, since Nigel Farage as well Godfrey Bloom were "pale as a sheet" next to him (Sommer, 2014a). Further on, he argued that the success of the New Right would be ensured by the freshness effect and their permanent presence in the media without being accountable for any political decisions.

Joanna Lichocka from "Gazeta Polska" tried to mobilize the right-wing electorate to take part in the European elections. In her article Szansq PiS-u frekwencja $i$ młodzi [PiS's chances lie in the young and a high turnout], the journalist argued that if the opposition failed to achieve a good result in these elections, Donald Tusk and PO could continue to rule in the years to come. The author particularly emphasized the psychological outcomes of a potential victory of the "quarreling and emotionally wobbly [ruling coalition] for whom these elections are of particular importance" (Lichocka, 2014a). Further on, the author stated that PO was trying to use the campaign to distract from corruption allegations. Additionally, they reportedly illegally used schools and public administration buildings for election purposes thereby breaching electoral protocol (ibid.).

All the leading Polish newspapers and magazines stressed the lack of a substantive and honest campaign. Journalists observed that the election committees of the political parties applied various social engineering instruments to drum up votes and took advantage of negative campaign elements.

On May 7, "Zielony Sztandar" published information about a new election spot presented by Adam Jarubas, the head of the PSL election committee. The commercial focused on the issue of Poland's security. It stressed that national security not only involved grenades, tanks and aircraft, but also the lack of the necessity to leave the country to look for jobs abroad and the ability to make your dreams come true here. According to PSL, security also encompassed "a modern countryside which yields bread, vegetables and fruit from fertile fields and fragrant orchards" (No author, "Zielony Sztandar", 2014).

At the same time, Jakub Halcewicz-Pleskaczewski from "Gazeta Wyborcza" observed that in the struggle for votes, the competing parties mainly employed negative campaigns and their leaders did not care much for the low level of knowledge about the EP among Polish society. The journalist referred to a poll conducted by TNS Polska which showed that $40 \%$ of the respondents did not know that MEPs are elected in general elections, and $69 \%$ were unable to name a single Polish MEP. There were also respondents who mentioned Donald Tusk ${ }^{4}$ as an MEP. Such blatant ignorance as concerns EU institutions motivated the journalist to try to change this situation. He directed readers to the MamPrawoWiedziec.pl website, especially designed by NGOs in order

\footnotetext{
3 Janusz Korwin-Mikke is a founder and leader of the New Right and Member of the European Parliament, elected in 2014 (translator's note).

${ }^{4}$ At the time of the poll, Donald Tusk was Prime Minister of Poland and the leader of the ruling PO party (translator's note).
} 
to make Polish society aware of the standpoints of Polish candidates for the EP (Halcewicz-Pleskaczewski, 2014).

In the same newspaper, Paweł Wroński published the article Kaczynnski stracit szansę by być przyzwoitym [Kaczyński has lost the chance to be decent], where he noted that as the European elections drew nearer, the PiS campaign was becoming increasingly aggressive. He referred to the statement of PiS deputy Krystyna Pawłowicz, who spoke about Professor Władysław Bartoszewski as a low-class shepherd, and to the President of PiS, Jarosław Kaczyński, who accused Professor Bartoszewski, a former prisoner of Auschwitz and a fighter in the Warsaw Uprising, of having received the financial Prize of Robert Bosch for his achievements in shaping Polish-German relations. In the opinion of Kaczyński, Professor Bartoszewski defended the interests of Germany while pretending to be impartial (Wroński, 2014). In Wroński's opinion, PiS realized that the turnout in the elections would be low, and by attacking Bartoszewski the party was trying to mobilize its infallible, cast iron electorate.

On May 9, 2014, "Gazeta Wyborcza" assessed the European election campaign conducted by SLD. In the article SLD umęczony jak czarny kon [SLD exhausted as a dark horse], Agata Nowakowska noted that after ex-Prime Minister Leszek Miller was elected head of the party, its supporters' hope of victory over PO and PiS revived. In the journalist's opinion, SLD started a very intensive election campaign, it "organized the Congress of the Polish Left with great fanfare last year, refreshed the party platform, pampered former members of the Communist Party, founded the Congress of Women of the Left, pompously celebrated the fifteenth anniversary of alliances - all to inspire the supporters' faith in victory" (Nowakowska, 2014). The election campaign also featured a tour of 'the red bus' around Poland, and SLD members boasted of having had as many as 134 meetings with their voters during the May weekend. The leitmotif of the SLD campaign was the tenth anniversary of Poland's membership of the EU and the merits of Prime Minister Miller's government, who finalized the accession decision. The journalist of "Gazeta Wyborcza" claimed that, given the lack of Polish society's interest in European matters, SLD emphasized domestic matters in the European campaign. For instance, they were collecting signatures under an SLD motion to increase the lowest pension by 200.00 zloty, abandon short-term employment contracts ("junk contracts") and raise the minimum hourly rate to ten zlotys (ibid.). In Nowakowska's opinion, the results of the polls were not advantageous for SLD. The author viewed this, harking back to the origins of the party, praising the period of Edward Gierek $^{5}$ and referring to how elderly the party leaders were.

During the campaign prior to the European elections, the Polish press also addressed the issue of the image of the EP in Polish public opinion. Adam Leszczyński observed in "Gazeta Wyborcza" that the image of the EP is typically associated with two stereotypes: as providing a "salary for meritorious activists or loot for crooks and idlers" (Leszczyński, 2014). In his article Za mało namystu, za dużo o kasie [Too little

5 Edward Gierek was the leader of the Polish Communist party (PZPR) from 1970-1980. The beginning of this period was the time of a marked increase of living standards and improved relations with the West, for which Gierek was initially hailed a miracle-worker and continues to be associated with the relative prosperity of Poland (translator's note). 
consideration, too much about cash], Leszczyński said that the political parties treated the European elections as an exile for those first-class politicians who failed to attain their political goals at home. Therefore, he was not surprised with the low turnout forecasted by the Public Opinion Research Center (CBOS). According to the data collected in March 2014, even fewer voters were going to go to the polls than five years earlier (the turnout in the 2009 European elections amounted to $24.5 \%$ in Poland). The same survey showed that $71 \%$ of respondents expressed an utter lack of interest in the European elections, and that society believed that Polish MEPs did not have much to do in Strasbourg.

Another journalist of "Gazeta Wyborcza", Renata Grochal in the article Lokomotywy partyjne na każde wybory te same [Party locomotives the same in every election] emphasized a certain rule of European elections. Political parties betted on the most recognizable faces, after winning an EP mandate, returning to Poland to participate in another domestic parliamentary or presidential election. Suggesting the double standards of politicians, the journalist quoted Zbigniew Ziobro, President of the United Poland party, who said; "If we did not stand for the EP it would mean that we are retiring from politics. But for some of us domestic policy is most important. We are honestly signaling that some of us are likely to run in other elections" (Grochal, 2014a). The journalist observed that the practice of abandoning mandates before the end of the election term occurs in all political parties and is not a Polish invention. The renowned sociologist, Jarosław Flis, said that "behaving in this manner the parties are counting on less than rational voters who are looking for famous names on the lists and are not much interested in what happens thereafter" (ibid.).

As the elections drew nearer, the leading Polish magazines were forecasting the election success of the party of Janusz Korwin-Mikke, the New Right, in surpassing the $5 \%$ threshold. The Editor-in-Chief of the "Instytut Idei" and the head of the Civil Institute (Instytut Obywatelski), Jarosław Makowski, stated that for several years we had been dealing with an electorate fueled by grievance and protest whose chosen leader in these elections was precisely Janusz Korwin-Mikke. "This is a group of $6-8 \%$ of the electorate who become active around every election. Every time they find a different reason for mobilizing, a different leader and different reasons to protest and express their grievances. This group is strong enough to launch a marginal party into the main current of politics, but weak enough not to be able to actually upset the political order" (Makowski, 2014).

The head of the think tank associated with PO observed that the party which wins the support of such a "floating electorate" can find themselves in the dustbin of history as rapidly as they entered politics, because the sentiments of their electorate are changeable and it "quickly gets bored with its new idol, treating it somewhat like a toy which is thrown away when it stops bringing joy" (ibid.). Such a scenario was forecast by Jarosław Makowski for the head of the New Right.

The leader of the New Right disclosed the true intentions for their participation in the European elections in "Newsweek". The main goal for him and his party was to succeed in the national elections, to disprove the claims made by some voters that a vote cast for Korwin-Mikke is a wasted vote. Therefore, the party treated the European elections as a platform for entering the domestic political arena. "I am going to the Euro- 
pean Parliament to overthrow the Union using the Union's money [...] Union money, immunity, free travel - all have their significance. We are going to use them brazenly. We will take money from the Union and we will use this money to overthrow it from the inside $[\ldots]$ The Union is an entity appropriated by a gang of socialists. Under the Union's occupation, even Germany is being finished off. All this rotten structure is dying, there is no economic development, children are not being born, there is an utter moral collapse. These people need to be shot for genocide" (Pawlicka, 2014), declared the leader of the conservative liberals.

Zdzisław Krasnodębski called in "Gazeta Polska" for a more Polish Europe after the end of the election campaign. He assessed Poland's membership of the European Union, remarking that the media only stress what Poles received from the Union, failing to mention what Poland gave to a united Europe. Therefore, instead of the re-Christianization of Europe we are faced by its genderization. In the opinion of the author, who is closely associated with PiS, "we can and we should share our freedom and our Christian and national tradition with Europe [...] instead of becoming increasingly German, Europe should become a bit more Polish" (Krasnodębski, 2014).

On home stretch of the campaign, Polish journalists were in agreement that the election campaign for the European Parliament lacked energy, commitment and original ideas. Jerzy Domański observed in "Przegląd" that the situation was complicated by the electoral law: "European electoral law is devious, it dishonestly gives preference to the favorites of party apparatus, and is utterly incomprehensible to voters" (Domański, 2014b). All the leading newspapers and magazines in Poland stressed the lack of serious and substantial debate (Wroński, 2014b).

On May 14, 2014, "Gazeta Wyborcza" noted that on the occasion of the approaching anniversary of the Battle of Monte Casino, Donald Tusk would both take part in the celebrations of the $70^{\text {th }}$ anniversary of the battle and meet Pope Francis. A journalist from "Gazeta Wyborcza", Renata Grochal, indicated that this was not a coincidence, but social engineering. In this manner, $\mathrm{PO}$ was trying to win the support of the undecided electorate among people over 55 years of age. These people remember the war, they fear the crisis across the eastern border, attach importance to historical anniversaries and are closely attached to the Catholic Church (Grochal, 2014b). In the opinion of the journalist, another favorable circumstance for $\mathrm{PO}$ was the media coverage of the Ukrainian issue and the tenth anniversary of Poland's membership of the EU.

The Polish press also presented an assessment of the election campaign conducted by the leading political parties in rural areas. "Zielony Sztandar" reported on a folk festival held in the cradle of the people's movement - Rzeszów, on May 18. The festival was attended by a number of prominent politicians from PSL, including the Minister of Labor and Social Policy Władysław Kosiniak-Kamysz, the PSL leader in the Podkarpacie region Jan Bury, and candidates for the EP: Dariusz Dziadzio, Alicja Wosik, Stanisław Bartman and Justyna Piekut. In a long speech, Jan Bury, President of the Regional Board of PSL in Rzeszów, addressed the benefits Poland enjoyed on account of its EU membership. In the context of the approaching elections, Bury warned against the parties that wanted to destroy the Union from the inside, which meant that they wanted to destroy an order that was ideal for Poles: "Ukrainians, Moldovans and Georgians would love to live in such a Europe" (Pieniazzek, 2014). He also stressed the role 
of PSL in building the Third Polish Republic: "some of you can say that you have had 5, $6,7,8,9 \%$ [of the vote], and have not exceeded $10 \%$ for many years. But this $8 \%$ we do have means more than $40 \%$ in opposition. Because we have an influence on what is happening. We have an influence on Union measures, on national and regional programs. On how Union money will be spent. This is not influenced by the opposition, by the malcontents of the entire European Union" (ibid.).

"Gazeta Wyborcza" stressed other accents of the election campaign in rural areas. Agata Nowakowska stated that the President of PiS became a major farmer in Poland. She referred to the statistics from CBOS, showing that rural Poland votes primarily for PiS and PO, and only after that for PSL. The polls also evidenced that PiS enjoys the support of farmers who own smaller plots of land (3-4 ha), PSL unites those in possession of 4-50 ha and PO is mainly supported by farmers in possession of over 300 ha of land (Nowakowska, 2014b). The journalist also assessed the political parties' election platforms addressed at the rural electorate. In her opinion, PiS presented a social platform aimed at impoverished farmers. Its main assumptions were related to allowances. In her opinion, this platform was good for poor farmers, but it did not give them any development opportunities. Election slogans also concerned religious issues and worldview: "they advertise food that is free from GMO and from ritual slaughter" (ibid.). In contrast, PSL - ideologically associated with farmers - approached the campaign substantively, frequently retorting PiS statements on the embargo on Polish meat in Russia, the size of Polish exports and benefits Polish agriculture had gained from EU membership.

On May 19, Tomasz Bielecki, a reporter for "Gazeta Wyborcza" in Brussels, in his article Po co nam Parlament Europejski [What do we need the European Parliament for?] tried to mobilize the electorate to participate in the May 2014 elections to the EP. He listed the most important tasks of the EP (such as co-deciding about the costly agricultural and energy policies, Union funds and budgetary policy) and pointed to the numerous merits of MEPs which would be increasingly noticeable for European society, as the powers of the EP increased. Among the most important tasks, he identified the reduction of telephone roaming charges, eventually leading to the elimination of roaming fees altogether, reduced $\mathrm{CO} 2$ emissions, combating the project to ban the production of menthol and slim cigarettes, protecting Europe from US espionage and rejecting the ACTA agreement advocated by the US since 2012 (Bielecki, 2014). The journalist from "Gazeta Wyborcza" referred to the statement by Agnieszka Łada, an expert in the Institute of Public Affairs, who indicated that "voter turnout in the European elections has an impact on the prestige of EU members. If Polish citizens showed in the elections that they wanted to co-decide about the fate of the Union and they cared for it, it would doubtlessly strengthen the authority of Poland in discussions on the Union's future" (ibid.).

Jerzy Domański in "Przegląd" observed that our absence from the European elections would mean "a walkover and a bonus for those we surely do not want in Brussels" (Domański, 2014c). Renata Grochal published the article Po co nam europostowie, po co nam europarlament? [Why do we need MEPs, and what do we need the EP for?] in "Gazeta Wyborcza", where she stressed that the next elections to the EP were extremely important not only for the European Union but also for Poland, and it was up to us, the 
voters, to decide who would become our representatives in Brussels. She presented the standpoints of different election committees on those European issues that were essential for Poland, such as membership of the euro zone, the establishment of a European army, subsidies to agricultural production, strengthening economic sanctions towards Russia, employment migration, Poland's accession to banking union and transforming the EU into a federation. She also indicated that a number of these issues were absent from the current election campaign in Poland. She also observed that the EP was facing new challenges and serious tasks in its new term of office. Among other things, the EP would run consultations on the agenda of tasks for the new European Commission, negotiate the agreement on free trade and investments with the US and further unification of the EU's internal market. In her opinion, the EU was expecting a difficult fall, since the new voting system in the Council of the European Union would come into effect in November - the system of double majority, which increases the power of the votes cast by the largest EU members (Grochal, 2014b). She also noted that the EU was about to launch common banking supervision, which curbed the role of national controlling institutions. Therefore, the journalist argued that the voice of the electorate and Polish participation in the European elections was of immense importance. However, Polish politicians not only never made the decision about when to enter the euro zone but, instead, during the election campaign were tackling marginal issues: "we have a festival of silly election spots, politicians preferred to take measurements of their waists, sing songs or compete on being more anticlerical than others" (ibid.) she concluded.

The journalists from "Polityka", Mariusz Janicki and Wiesław Władyka, presented a similar assessment of the European campaign. In their opinion, the 2014 campaign was characterized by sluggishness, a lack of ideas and deadly routine "as if a restaurant band had to play For he's a jolly good fellow for the thousandth time in the small hours" (Janicki, Władyka, 2014). They primarily blamed the politicians for this state of affairs, for not having any ideas how to convince their electorates to vote for them, whether at meetings, or during TV debates and in election spots: "nobody has come up with a bigger idea, a fresh social concept or an innovative economic vision" (ibid.). On the other hand, they noted that society showed no interest in the European elections. Therefore, they called the election campaign a 'sidewalk campaign', ${ }^{6}$ while the political marketing techniques used in these elections were compared to those at the level of a local store, where everything was equally important: the situation in Ukraine, a Papal audience, Jarosław Kaczyński's new sweater, the flood, a book by Piskorski, Kwaśniewski's money and the bearded woman in the Eurovision Song Contest (ibid.). In their opinion, however, we should not rely only on the content of the average election campaign. This is not important, the elections are important, and that is why they encouraged the electorate to take part in the European elections. In their extensive article, they also noted that a majority of polls indicated that the main contest again concerned the choice between PO and PiS, since these two major parties expressed the ideological emotions of modern Poles.

${ }^{6}$ This is an allusion to the activities of local authorities who become particularly active before the elections finishing various projects, such as laying sidewalks in their constituency (translator's note). 
Three days before the European elections, "Gazeta Wyborcza" published a Euro-ranking featuring the profiles of the five best and worst MEPs from the previous term. The journalists compiled it on the basis of such criteria as the statistics of their speeches, reports, amendments, interjections, as well as their contacts with other MEPs. In the assessment of the newspaper, in the period from 2009-2014 Poland was best represented by Danuta Hübner (among other things for chairing the commission on regional development and supervising the regulations on cohesion policy which favored Poland), Jacek Saryusz-Wolski (among other things for commitment to Ukrainian issues and establishing the Parliamentary Assembly of the Eastern Partnership), Jerzy Buzek (among other things for high regard he enjoys as an efficient Union official and to some extent for presiding over the EP), Jan Olbrycht (among other things for his contribution to cohesion policy and regional funds), Wojciech Olejniczak (among other things for his activities in the committee on regional development, as well as agriculture and rural development) and Róża Thun (for her activities in the committee on the internal market and consumer protection).

The term served by the following MEPs was considered as wasted: Zbigniew Ziobro, Jacek Kurski and Tadeusz Cymański from the 'Ziobro team' (among other things for their support for Nigel Farage, leader of the UK Independence Party, a populist, anti-immigration, xenophobic and to a certain extent anti-Polish party). In the opinion of the journalists, Marek Migalski from United Poland also wasted his five years in the EP. He penned the book Parlament antyeuropejski [Anti-European Parliament] where he described the system of legal corruption in the EU he was a part of, gaining enormous profits himself (no author, "Gazeta Wyborcza", 2014).

\section{After the elections}

After the election results were officially announced, there were numerous comments in the Polish press. Politicians were condemned and blamed for the low turnout and ignorance of society as regards the activities of the EP. The winners were discussed, that is $\mathrm{PO}$ and $\mathrm{PiS}$, and particular attention was paid to the staggering result of the New Right, the party of Janusz Korwin-Mikke. Polish journalists were trying to come up with the post-election scenarios for these parties.

Polish journalists also evaluated the losers, in particular the EPTR Alliance, which - having failed to exceed the $5 \%$ election threshold - was in their opinion going to disappear from politics.

Tomasz Sommer in "Najwyższy Czas" announced the victory of conservative-liberals and libertarians in the 2014 election. Given these new circumstances he forecasted the new role to be played by Korwin-Mikke's party, which was to tip the scales when the government is formed after the next parliamentary election. In Sommer's opinion, this would be a government of experts rather than party activists and coteries, that would lead to the "radical deregulation, reduced taxes and social security payments as well as the liberalization of the entire state structure, since this is what a majority of Poles clearly want" (Sommer, 2014c).

Janina Paradowska observed in "Polityka" that these European elections reinforced the division of the political stage as PO and PiS recorded a huge advantage over other 
Polish political parties. In her opinion, the result achieved by the third party in succession, SLD, was an average one, but the fact that this party by far outstripped the EPTR alliance with its main driving forces, Kazmierz Kutz and Ryszard Kalisz, supported by Aleksander Kwaśniewski, was awe-inspiring. She considered the New Right of Janusz Korwin-Mikke as the dark horse of these elections, although "radicalism and the intention to blow up the European Union are hardly popular" in Poland (Paradowska, 2014). This renowned journalist also stressed the fact that, ironically, Europe was far from being the main issue in these European elections of May 25, 2014.

Robert Matejuk from "Zielony Sztandar" deemed the $6.8 \%$ of votes gained by PSL to be an unquestionable success. In his opinion, PSL owed this success to several factors, such as "very active and hard working, excellent candidates (Janusz Piechociński, Jarosław Kalinowski, Czesław Siekierski, Andrzej Grzyb) backed by their election committee, headed by Adam Jarubas, the publication of newspapers and magazines that presented the achievements of PSL and reached half a million of their electorate, and - first and foremost - a positive and topical campaign: PSL did not attack anybody on the left or on the right. This demonstrated that PSL was tackling actual problems that could be resolved" (Matejuk, 2014).

Joanna Lichocka from "Gazeta Polska" stated that the European elections in Poland ended in a draw, since PO's victory amounted to gaining 24,000 votes more than PiS. In her article Ostatni taki wynik $P O$ [The last such $\mathrm{PO}$ result], she said that, given such a low turnout, the party of Donald Tusk could face defeat in the next national elections. In her opinion, the true winner of these European elections was PiS, which gained its best result in the European elections so far. Translating this result into Polish reality, she said that "unless something serious happens, or PiS makes serious mistakes, it should win in the local elections, and then in the parliamentary elections, and it should win clearly" (Lichocka, 2014b).

Grzegorz Rzeczkowski from "Polityka" commented on the result of the New Right of Janusz Korwin-Mikke. The journalist referred to the results of the survey conducted by the IPSOS research center for the television stations TVP and TVN 24, which indicated that the New Right mainly won the votes of educated males in the 18-25 age brackets. The election campaign of Korwin-Mikke's party was described as taking support from other parties, in particular EPTR (having gained the votes of over 18\% of its electorate from 2011). In the journalist's opinion, this was mainly caused by the party leader's instability, changeability and impatience, making him increasingly difficult to define politically. By contrast, Korwin-Mikke was a model of stability: "populistically expressive, he achieved rhetorical mastery thanks to the thousands of debates, TV disputes and countless meetings with voters he attended, driving his old Hyundai around Poland" (Rzeczkowski, 2014). For the journalist, the advantage of Korwin-Mikke's campaign lay in his long presence in politics, being an active blogger on the internet, and his conservative and liberal outlook presented for over twenty years. In his opinion, this directness attracted the young electorate, which chose Korwin-Mikke instead of Palikot this time. The journalist of "Polityka" warned, however, that the favor of the young electorate was particularly volatile: "if in their opinion Korwin-Mikke crosses a thin line of being ridiculous and exaggerates his eccentricity, his fortunes can reverse" (ibid.). 
A definite majority of Polish journalists was critical of the commitment of Polish parties to the European elections. The campaign was assessed as chaotic, based on 'cheap tricks' similar to those used in previous elections. The journalists stated that politicians mainly wanted to remind the electorate of themselves before the approaching local and parliamentary elections, so they treated the European elections as a warm-up before the national elections. Similar to former elections (in 2004 and 2009), this campaign lacked substantial serious topics related primarily to European issues. Therefore, it is hardly surprising that the turnout was disappointing and Polish society once again manifested its anti-institutional attitudes, involving a lack of faith in the power of their votes cast and disbelief in democratic election principles.

\section{Bibliography}

Bielecki T. (2014), Po co nam Parlament Europejski, “Gazeta Wyborcza” May 19.

Burzyńska A. (2014), Kogo zetnq wybory?, "Wprost” May 25.

Domański J. (2014a), Twarze Eurokandydatów, "Przegląd” April 22-May 4.

Domański J. (2014b), Pogrywanie kobietami, "Przegląd" May 12-18.

Domański J. (2014c), Walkower sprzyja miernotom, "Przegląd" May 19-25.

Grochal R. (2014a), Lokomotywy partyjne na każde wybory te same, "Gazeta Wyborcza" May 13.

Grochal R. (2014b), Tusk walczy o wyborce 55+, "Gazeta Wyborcza” May 14.

Grochal R. (2014), Po co nam euro postowie, po co nam euro parlament, "Gazeta Wyborcza” May 20.

Halcewicz-Pleskaczewski J. (2014), Broń wyborcy to pytania, "Gazeta Wyborcza” May 8.

Janicki M., Władyka W. (2014), Powaga kabaretu, "Polityka" May 21-27.

Kik K. (2014), Towar polityczny drugiej kategorii, "Rzeczpospolita" May 7.

Kondzińska A. (2014), Schizofrenia narodowców, "Gazeta Wyborcza” May 2-4.

Krasnodębski Z. (2014), Powalczmy o bardziej polskq Europe, "Gazeta Polska” May 21.

Kublik A. (2014), Niemrawa ta kampania, "Gazeta Wyborcza May 7, 2014.

Leszczyński A. (2014), Za mało namystu, za dużo o kasie, "Gazeta Wyborcza” May 10.

Nowakowska A. (2014), Wędzona kiełbasa wyborcza Kaczyńskiego, "Gazeta Wyborcza” May 15.

Lichocka J. (2014a), Szansq PiS-u frekwencja i młodzi, "Gazeta Polska” May 7.

Lichocka J. (2014b), Ostatni taki wynik PO, "Gazeta Polska” May 28.

Majewski P. (2014a), Wyborcy nie widzq kampanii, "Rzeczpospolita" April 25.

Majewski P. (2014b), Kto narzuci temat na finat kampanii?, "Rzeczpospolita” May 6.

Makowski J. (2014), Fruwajacy elektorat buntu, "Gazeta Wyborcza” May 16.

Matejuk R. (2014), PSL też wygrało, "Zielony Sztandar” May 28-Jue 3.

Nasz euroranking (2014), "Gazeta Wyborcza” May 21, p. 10-11.

Nowakowska A. (2014), SLD umęczony jak czarny koń, "Gazeta Wyborcza” May 9.

Nowicka K. (2014), Pudelek Europejski, "Wprost” March 30.

Olczyk E. (2014), W poszukiwaniu kozła ofiarnego, "Rzeczpospolita” May 5.

Paradowska J. (2014), Prawie remis, "Polityka" May 28-June 3.

Pawlicka A. (2014a), Co myśli wyedukowany idiota, "Newsweek" May 5-11.

Pawlicka A. (2014b), Antychryst, "Newsweek" May 12-18. 
Pieniążek S. (2014), Święto ludowe w Rzeszowie, "Zielony Sztandar” May 21-27.

Pieńkowski M. (2014), Triki PiS z kandydatami, "Rzeczpospolita" April 24.

PSL o bezpiecznej Europie (2014), “Zielony Sztandar” May 7-13.

Reczkowski G. (2014), Korwiniada, "Polityka" May 28-June 3.

Słojewska A. (2014), Polska czołówka w Brukseli, "Rzeczpospolita" April 22.

Sommer T. (2014), Scenariusz powyborczy A.D. 2014, "Najwyższy Czas” May 17.

Sommer T. (2014), Teraz tylko do przodu, "Najwyższy Czas", May 31.

Stankiewicz A. (2014), Milionerzy jednej kadencji, "Rzeczpospolita" April 23.

Wroński P. (2014a), Kaczyński stracit szansę by być przyzwoitym, "Gazeta Wyborcza” May 12.

Wroński P. (2014b), Jesus Christ! Ale eurodebata, "Gazeta Wyborcza” May 16.

\section{Summary}

The paper presents the opinions of Polish journalists on the results of the elections to the European Parliament in Poland in 2014. The paper discusses the style of the election campaigns conducted by the different political parties. It also assesses the degree to which politicians and society were involved in the European elections. The paper presents the profiles of EP members published in the Polish press. The analysis is conducted on the basis of articles published from April 15 till May 27, 2014 in "Gazeta Wyborcza", "Rzeczpospolita", "Zielony Sztandar", "Przegląd", "Gazeta Polska", "Najwyższy Czas", "Polityka", "Wprost" and "Newsweek".

Key words: European Parliament, political parties, European election, election campaign, MEPs, Polish press

\section{Prasa polska o wyborach do Parlamentu Europejskiego w Polsce w 2014 roku}

\section{Streszczenie}

W artykule zaprezentowano opinie publicystów prasy polskiej na temat wyników wyborów do Parlamentu Europejskiego przeprowadzonych w Polsce w 2014 roku. W artykule zwrócono uwagę na style prowadzenia kampanii wyborczej przez partie polityczne. Oceniono także stopień zaangażowania polityków oraz społeczeństwa w Eurowybory. Opisano również sylwetki eurodeputowanych przedstawiane w prasie polskiej. Analizy dokonano na podstawie artykułów opublikowanych w dniach 15.04-27.05.2014 r. na łamach: "Gazety Wyborczej”, "Rzeczpospolitej”, “Zielonego Sztandaru”, "Przeglądu”, “Gazety Polskiej”, "Najwyższego Czasu”, "Polityki", "Wprost" oraz "Newsweeka".

Słowa kluczowe: Parlament Europejski, partie polityczne, Eurowybory, kampania wyborcza, Eurodeputowani 
